\title{
Virulence and antimicrobial resistance factors of Enterococcusspp. isolated from fecal samples from piggery farms in Eastern Cape, South Africa
}

Benson C Iweriebor ${ }^{1,2^{*}}$, Larry C Obi ${ }^{3}$ and Anthony I Okoh ${ }^{1,2}$

\begin{abstract}
Background: Enterococci have emerged as an important opportunistic pathogen causing life-threatening infections in hospitals. The emergence of this pathogen is associated with a remarkable capacity to accumulate resistance to antimicrobials and multidrug-resistance particularly to vancomycin, erythromycin and streptomycin have become a major cause of concern for the infectious diseases community. In this paper, we report the prevalence of Enterococcus in respect to species distribution, their virulence and antibiogram profiles.
\end{abstract}

Methods: Four hundred fecal samples were collected from two piggery farms in the Eastern Cape Province of South Africa. Enterococcus species were isolated and confirmed with generic specific primers targeting the tuf gene (encoding elongation factor). The confirmed isolates were speciated with enterococci species specific primers that aimed at delineating them into six species that are commonly associated with infections in humans. Antibiotic susceptibility testing was performed by disc diffusion method. Six virulence genes and antimicrobial resistance profiles of the isolates were evaluated molecularly.

Results: Molecular identification of the presumptive isolates confirmed 320 isolates as Enterococcus spp. Attempt at speciation of the isolates with primers specific for E. faecalis, E. durans, E. casseliflavus, E. hirae and E. faecium delineated them as follows: E. faecalis (12.5\%), E. hirae (31.25 \%), E. durans (18.75 \%) and E. faecium (37.5 \%) while E. casseliflavus was not detected. All the isolates were resistant to vancomycin, streptomycin and cloxacillin, and to at least two different classes of antibiotics, with 300 (93.8\%) isolates being resistant to five or more antibiotics. Also, three out of the six virulence genes were detected in majority of the isolates and they are Adhesion of collagen in $E$. faecalis (ace) (96.88 \%), gelatinase (gelE) (93.13\%) and surface protein (esp) (67.8\%).

Conclusion: There was high prevalence of multi-resistant vancomycin Enterococcus spp. (VREs) in the fecal samples of pigs in the farms studied, and this poses health implications as vancomycin is an important drug in human medicine. Further studies are needed to determine the spread of vancomycin resistance among bacteria of human origin in the communities.

Keywords: Virulence factors, Multiple antimicrobial resistance, vancomycin resistance, Enterococcus spp

\footnotetext{
* Correspondence: biweriebor@ufh.ac.za

'SA-MRC Microbial Water Quality Monitoring Centre, University of Fort Hare, Alice 5700Eastern Cape, South Africa

${ }^{2}$ Applied and Environmental Microbiology Research Group, Department of Biochemistry and Microbiology, University of Fort Hare, Alice 5700Eastern

Cape, South Africa

Full list of author information is available at the end of the article
}

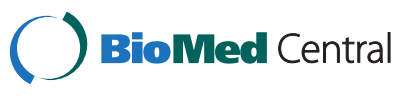

(c) 2015 Iweriebor et al. This is an Open Access article distributed under the terms of the Creative Commons Attribution License (http://creativecommons.org/licenses/by/4.0), which permits unrestricted use, distribution, and reproduction in any medium, provided the original work is properly credited. The Creative Commons Public Domain Dedication waiver (http:// creativecommons.org/publicdomain/zero/1.0/) applies to the data made available in this article, unless otherwise stated. 


\section{Background}

Generally, antibiotic-resistant pathogens are able to cause a major clinical challenge in both human and animals. Enterococcus spp., ubiquitous in nature and a common commensal of the intestinal microbiota of humans and animals, have emerged as one of the most prevalent nosocomial pathogens worldwide [1]. Several factors such as their propensity and inherent ability to acquired resistance to antimicrobials [2], putative virulence traits, biofilm forming capability [3], and ability to horizontally transfer antimicrobial resistance and virulence determinants to other bacteria [4] are attributable to these abilities.

Enterococcus spp. are Gram-positive bacteria known to possess a low level of pathogenicity and can cause urinary tract infections, endocarditis, peritonitis, among other diseases. [5, 6]. Until 1988, Vancomycin was one of the preferred antibiotics for the treatment of infections caused by Enterococcus spp. But this seems to have changed when the first vancomycin-resistant Enterococcus spp. (VREs) were isolated and identified in Great Britain[7]. Also, VREs have been detected and isolated in many countries throughout the world thus heightening the sense of urgency regarding the global presence of antibiotic resistant enterococci[810]. As infections caused by VREs are difficult to treat, VRE should be considered a dangerous pathogen as it could easily spread to people with compromised immune system. The risk of death from vancomycin-resistant enterococci (VRE) is has been reported to be about $75 \%$, compared with $45 \%$ for those infected with a susceptible strain [11]. According to the degree of resistance to vancomycin and teicoplanin, as well as the origin and transferability of the antibiotic resistance genotype, VREs are categorized as expressing the $\operatorname{van} \mathrm{A}, \operatorname{van} \mathrm{B}$, or $\operatorname{van} \mathrm{C}, \operatorname{van} \mathrm{D}, \operatorname{van} \mathrm{E}$ and $\operatorname{van} \mathrm{G}$ phenotypes $[12,13]$. The vanA phenotype shows a high level of resistance to both vancomycin and teicoplanin, while the $v a n \mathrm{~B}$ phenotype shows various levels of resistance to vancomycin but is sensitive to teicoplanin. The van $\mathrm{C}$ phenotype can be further divided into 3 classes, van $\mathrm{C}-1$, van $\mathrm{C}-2$, and van $\mathrm{C}-3$; van $\mathrm{C}-2$ and $v a n \mathrm{C}-3$ are expressed as van $\mathrm{C}-2 / 3$ because of their similar genetic sequence $[14,15]$. Vancomycin resistance among enterococci spread via the dissemination of mobile genetic elements of variants of the vanA-type element Tn1546 mostly located on conjugative plasmids $[16,17]$.

A variety of antibiotics are applied at both therapeutic and sub-therapeutic levels in the management of farm animals. Tylosin, a member of the macrolide family is widely used as antimicrobial growth promoters (AGPs). The use of avoparcin has been associated with high level of vancomycin-resistant enterococci in farm animals [18]. The possibility of transmission of bacteria from animals to humans is not limited to zoonotic diseases and the selection of a reservoir of resistant opportunistic human pathogens and possible transmissible resistance determinants through the indiscriminate use of antimicrobials in farm animal managements may have undesirable consequences for human health [18]. The ability of Enterococcus spp. to acquire antibiotic resistance through transfer of plasmids and transposons, chromosomal exchange, or mutation presents a significant challenge for therapeutic measures. In addition to this inherent capacity of enterococci to acquire resistance determinants, they possess several virulence factors. The virulence of this organism is associated with several genes such as ace (collagen binding cell wall protein), acm (surface-exposed antigen), agg (aggregative pheromone-inducing adherence to extra-matrix protein), esp (enterococcal surface protein), hyl (hyaluronidase), cad1 (pheromone cAD1 precursor lipoprotein), the cAM373 gene (sex pheromone cAM373 precursor), the cCF10 gene (pheromone cCF10 precursor lipoprotein), cob (pheromone cOB1 precursor/lipoprotein, YaeC family), cpd1 (pheromone cPD1 lipoprotein), cylABLM (hemolysin), efaAEfs (endocarditis-specific antigen), sagA (secreted antigen), and gelE (gelatinase) $[19,20]$. These virulence factors have been reported in enterococci isolated from food of animal origin [21].

The Eastern Cape Province of South Africa is largely rural and agrarian with many commercial piggery farms. The use of antibiotics to manage animal productivity is a common phenomenon and the impact of bacteria with resistance determinant shed into the environment through fecal materials of animal possess a huge epidemiological problem considering the fact that the province has one of the highest HIV/AIDS prevalence in the country. In this paper, we report on the virulence and antimicrobial resistance profiles of Enterococcus spp. isolated from fecal samples collected from piggery farms in the Nkonkonbe municipality in the Eastern Cape Province of South Africa

Table 1 List of primers and control strains

\begin{tabular}{|c|c|c|c|}
\hline Strain & Primer Sequence 5'-3' & $\begin{array}{l}\text { Product size } \\
\text { (bp) }\end{array}$ & Ref \\
\hline \multirow{2}{*}{$\begin{array}{l}\text { E. faecalis } \\
\text { ATCC } 19433\end{array}$} & FL1 ACTTATGTGACTAACTTAACC & 360 & 23 \\
\hline & FL2TAATGGTGAATCTTGGTTTGG & & \\
\hline \multirow{2}{*}{$\begin{array}{l}\text { E. durans } \\
\text { ATCC } 19432\end{array}$} & DU1 CCTACTGATATTAAGACAGCG & 295 & 23 \\
\hline & DU2 TAATCCTAAGATAGGTGTTTG & & \\
\hline \multirow{2}{*}{$\begin{array}{l}\text { E. casseliflavus } \\
\text { ATCC } 25788\end{array}$} & CA1 TCCTGAATTAGGTGAAAAAAC & 288 & 23 \\
\hline & CA2 GCTAGTTTACCGTCTITAACG & & \\
\hline \multirow{2}{*}{$\begin{array}{l}\text { E. faecium } \\
\text { ATCC19434 }\end{array}$} & GAAAAAACAATAGAAGAATTAT & 215 & 23 \\
\hline & FM2 TGCTTTTTTGAATTCTTCTTTA & & \\
\hline \multirow{2}{*}{$\begin{array}{l}\text { E. hirae } \\
\text { ATCC } 8043\end{array}$} & HI1 CTTCTGATATGGATGCTGTC & 187 & 23 \\
\hline & HI2 TAAATTCTTCCTTAAATGTTG & & \\
\hline
\end{tabular}


Table 2 Oligonucleotide primers used in this study to identify vancomycin resistance genes

\begin{tabular}{lllll}
\hline Gene(s) & Size (bp) & Primer sequence (5' to 3') & Region & Ref \\
\hline vanA & 314 & AF-GCGCGGTCCACTTGTAGATA & $105-124$ & 7 \\
& & AR-TGAGCAACCCCCAAACAGTA & $399-418$ & \\
vanB & 220 & BF-AGACATTCCGGTCGAGGAAC & $844-863$ & 7 \\
& & BR-GCTGTCAATTAGTGCGGGAA & $1044-1063$ & \\
VanC-1 & 402 & C1F-ATCCAAGCTATTGACCCGCT & $290-309$ & 7 \\
& & C1R-TGTGGCAGGATCGTITCAT & $672-691$ & \\
VanC-2/3 & 582 & C2F-CTAGCGCAATCGAAGCACTC & $100-119$ & 7 \\
& & C2R-GTAGGAGCACTGCGGAACAA & $662-681$ & \\
\hline
\end{tabular}

as part of our larger study on the reservoirs of antibiotic resistance in the environment.

\section{Materials and methods}

\section{Ethical clearance}

Ethical clearance was obtained from the University of Fort Hare ethics committee prior to sample collection and cooperation was sought from farmers from whose farms samples were collected.

\section{Study population and sampling}

Details on the study population and sampling procedures are as follows. Briefly, samples were collected from two commercial piggery farms in Nkonkonbe municipality within the Amathole Districts of Eastern Cape Province. A total of 400 samples from two farms were collected for the study. Rectal fecal samples were collected from individual breeder pigs using sterile swab sticks and to avoid duplication of sampling, the pigs were sampled while locked in their respective cages. After collection, samples were shipped on ice to the University of Fort Hare Microbiology laboratory for immediate processing. Data on antibiotic type and treatment history were collected with the purpose of describing the study population. Inventory of the antibiotics in the farmers refrigerators were taken during sampling. Sampling was done between June and August, 2014 at an interval of two samplings fortnightly.

\section{Laboratory detection of Enterococcus spp.}

The swab sticks were used to inoculate trypticase soya broth and incubated at $37{ }^{\circ} \mathrm{C}$ for 18 to $20 \mathrm{~h}$. These were then sub-cultured onto Bile Aesculin Azide agar and incubated at $37^{\circ} \mathrm{C}$ for $24 \mathrm{~h}$. Black dew drop colonies were assumed presumptive for Enterococcus species. One colony per plate was picked into a sterile trypticase soya broth and further incubated for $18 \mathrm{~h}$ at $37{ }^{\circ} \mathrm{C}$ for glycerol stock preparation and preservation at $-80{ }^{\circ} \mathrm{C}$ for future use.

\section{DNA Extraction}

To extract genomic DNA from the previously stored glycerol stocks, isolates were resuscitated in a $5 \mathrm{ml}$ Todd Hewitt broth at $37{ }^{\circ} \mathrm{C}$ for $20 \mathrm{~h}$ and cells were recovered from $2 \mathrm{ml}$ of the broth in a sterile Eppendorf and centrifugation was done at 5,000 rpm for $10 \mathrm{~min}$. The supernatant was discarded and the cell deposit washed with normal saline and further centrifuged at 5,000 rpm for $3 \mathrm{~min}$. The cell pellet was then re-suspended in a microcentrifuge tube containing rapid lysis buffer:-100 mM

Table 3 Oligonucleotides used in this study to amplify the enterococci virulence genes

\begin{tabular}{|c|c|c|c|c|c|}
\hline Gene & Virulence marker & Oligonucleotide sequence(5' to $\left.3^{\prime}\right)$ & $\begin{array}{l}\text { Product size } \\
\text { (bp) }\end{array}$ & $\begin{array}{l}\text { Annealing } \\
\text { temp }(C)\end{array}$ & References \\
\hline \multirow[t]{2}{*}{ As } & Aggregation & 1 CCAGTAATCAGTCCAGAAACAACC & 406 & 54 & 25 \\
\hline & & AS 2 TAGCTTTITTCATTCTTGTGTTTGTT & & & \\
\hline Ace & $\begin{array}{l}\text { Adhesion colaagen } \\
\text { in E. faecalis }\end{array}$ & ACE 1 AAAGTAGAATTAGATCCACAC & 320 & 56 & 25 \\
\hline \multirow[t]{2}{*}{ Gel } & Gelatinase & gel E1 AGTTCATGTCTATTTTCTTCAC & 402 & 56 & 25 \\
\hline & & gel E2 CTTCATTATTTACACGTTG & & & \\
\hline \multirow[t]{2}{*}{ EfaA } & E. faecalis antigen $\mathrm{A}$ & efaA1 CGTGAGAAAGAAATGGAGGA & 499 & 56 & 25 \\
\hline & & efaA2 CTACTAACACGTCACGAATG & & & \\
\hline \multirow[t]{2}{*}{ Esp } & Surface protein & Esp 46 TTACCAAGATGGTTCTGTAGGCAC & 913 & 58 & 32 \\
\hline & & Esp 47 CCAAGTATACTTAGCATCTITTGG & & & \\
\hline \multirow[t]{2}{*}{ CyIA } & Cytolisin & Cyl I ACTCGGGGATTGATAGGC & 688 & 56 & 32 \\
\hline & & Cyl lib GCTGCTAAAGCTGCGCTT & & & \\
\hline \multirow[t]{2}{*}{ Hyl } & Hyaluronidase & Cyl lib GCTGCTAAAGCTGCGCTT & 276 & 56 & \\
\hline & & $\begin{array}{l}\text { Hyl n1 ACAGAAGAGCTGCAGGAAATG Hyl n2 } \\
\text { GACTGACGTCCAAGTTTCCAA }\end{array}$ & & & \\
\hline
\end{tabular}




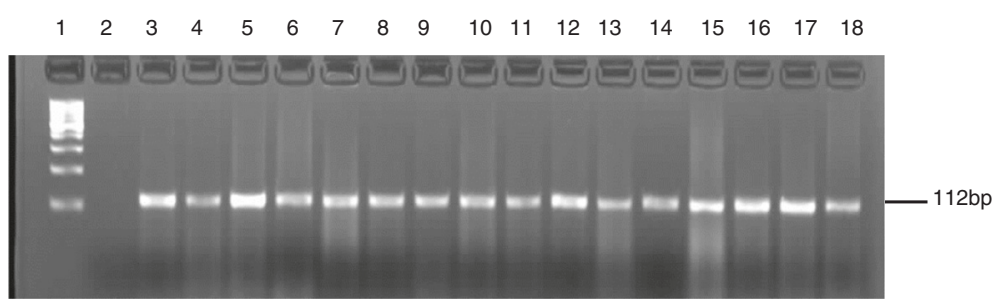

Fig. 1 Gel electrophoresis of PCR product of amplification of tuf gene for confirmation of Enterococcus genus. Lane 1 is the $100 \mathrm{bpMWM}$, lane 2 is the negative control, 3 is positive control E. faecium ATCC19434 while lanes 4 to 18 are amplicons derived from study isolates

$\mathrm{NaCl}, 10 \mathrm{mM}$ Tris-HCl pH8.3, 1 mM EDTA pH9.0; $1 \%$ Triton X-100, boiled for $15 \mathrm{~min}$ followed by centrifugation at 10,000 rpm and supernatant collected and stored at-20 ${ }^{\circ} \mathrm{C}$ for future use.

\section{Molecular confirmation of the isolates}

This preliminary approach stated above was then followed by polymerase chain reaction (PCR) identification analysis with Enterococcus genus-specific primers Ent 1 and Ent 2, as previously reported [22] with $E$. faecium ATCC19434 serving as the positive control. The tuf gene of the genus Enterococcus was amplified by PCR which was performed in a $25-\mu \mathrm{l}$ mixture of $5 \mathrm{x}$ buffer (supplied with Taq polymerase), $2.5 \mathrm{mmol} / \mathrm{l}$ of $\mathrm{MgCl}_{2}, 2.5$ $\mathrm{u}$ of Taq DNA polymerase, $200 \mu \mathrm{mol} / \mathrm{l}$ of each deoxynucleoside triphosphate, and $10 \mathrm{pmol}$ of each primer Ent1 5' -TACTGACAAACCATTCATGATG-3' and Ent2 R: 5' AACTTCGTCACCAACGCGAAC-3'. The PCR mixture was subjected to a 4-min denaturation step at $94{ }^{\circ} \mathrm{C}$, followed by 35 cycles of $60 \mathrm{~s}$ at $94{ }^{\circ} \mathrm{C}, 60 \mathrm{~s}$ at $53{ }^{\circ} \mathrm{C}$, and $60 \mathrm{~s}$ at $72{ }^{\circ} \mathrm{C}$, and a final elongation step for $5 \mathrm{~min}$ at $72{ }^{\circ} \mathrm{C}$. Verification of PCR products were performed in a $2 \%$ agarose gel electrophoresis at $110 \mathrm{~V}$ for $45 \mathrm{~min}$, visualized after staining with ethidium bromide in ALLIANCE.4.7 transilluminator and photographed.

\section{Species identification}

A multiplex polymerase chain reaction (PCR) was performed for Enterococcus species identification. Amplification of the genes related to the species-specific identification of $E$. faecalis, E. faecium, E. hirae, E. durans, and E. casseliflavus were performed as described previously by Jackson [23].
Two PCR master mixes consisting of different primer sets were prepared. Group 1 was E. durans, E. faecalis, and E. casseliflavus, and group 2 was E. faecium and $E$. hirae. The Dream Taq PCR Master Mix (2X) consisting of $4 \mathrm{mM} \mathrm{MgCl}_{2}, 0.4 \mathrm{mM}$ deoxynucleoside triphosphate mix and Taq polymerase enzyme (Thermo Scientific.) and $10 \mathrm{pMol}$ of each primer pair was added to constituted the reaction mixture in a PCR tube. Primers used are indicated in (Table 1). PCRs were performed in a final volume of $25 \mu \mathrm{l}$ consisting of $20 \mu \mathrm{l}$ of master mix and $5 \mu \mathrm{l}$ of DNA template. Following an initial denaturation at $95{ }^{\circ} \mathrm{C}$ for $4 \mathrm{~min}$, products were amplified in 30 cycles of denaturation at $95^{\circ} \mathrm{C}$ for $30 \mathrm{~s}$, annealing at $52{ }^{\circ} \mathrm{C}$ (E.. faecalis, E. durans and E. casseliflavus) or $48{ }^{\circ} \mathrm{C}$ (for $E$. faecium and E. hirae) for $1 \mathrm{~min}$, and elongation at $72{ }^{\circ} \mathrm{C}$ for $1 \mathrm{~min}$ followed by a final extension at $72{ }^{\circ} \mathrm{C}$ for $7 \mathrm{~min}$. Five microliters of product was electrophoresed on a $2 \%$ Tris-borate-EDTA agarose gel containing $2 \mu \mathrm{g}$ of ethidium bromide/ml to verify amplification of the targeted genes at $110 \mathrm{~V}$ for $45 \mathrm{~min}$. DNA molecular weight marker $100 \mathrm{bp}$ was used as the standard and photographed under UV light transilluminator (ALLIANCE 4.7) Molecular Imager Gel Doc.

\section{Antibiotic sensitivity testing}

The antimicrobial susceptibility of all isolates were assessed according to the Kirby-Bauer disk-diffusion method [24] making use of antibiotic discs (MAST DIAGNOSTICS) which were dispensed by automated disc dispenser on Muller Hinton agar (MHA). The following antibiotic impregnated discs were used: clindamycin $(2 \mu \mathrm{g})$, imipenem $(10 \mu \mathrm{g})$, neomycin $(30 \mu \mathrm{g})$,

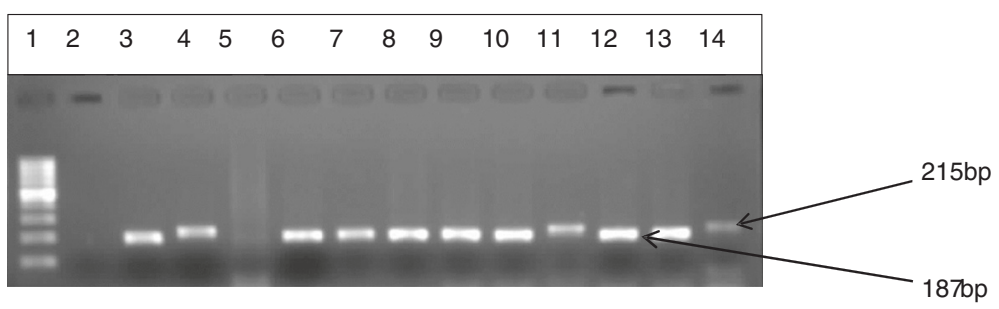

Fig. 2 Gel electrophoresis of multiplex PCR product for the speciation of the isolates positive for Enterococcus genus. Lane 1 is 100 bp ladder, lane 2 negative control and lanes 3 to 14 are E. hirae (187 bp) and E. faecium (215 bp), representatives of the positive isolates identified in this study 


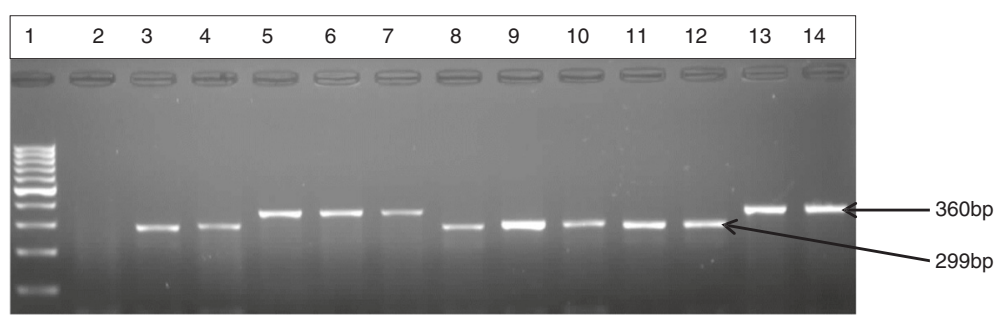

Fig. 3 Gel electrophoresis of PCR product multiplex PCR detection of E. faecalis, E. durans species isolated in this study. Lane 1 is 100 bp ladder, lane 2 negative control and lanes 3 to 13 are E. faecalis (360 bp) and E. durans (299 bp), representatives of the positive isolates identified in this study

streptomycin $(10 \mu \mathrm{g})$, vancomycin $(30 \mu \mathrm{g})$, penicillin $\mathrm{G}$ $(10 \mu \mathrm{g})$, amoxicillin-clavulanic acid $(10 \mu \mathrm{g})$, ciprofloxacin $(5 \mu \mathrm{g})$, cephalothin $(30 \mu \mathrm{g})$, cloxacillin (5ug), erythromycin (15ug) and amikacin (30ug). In the evaluation of the results, strains displaying intermediate resistance were regarded as resistant. All antibiotic discs contained the CLSI [24] approved concentration. The interpretations of zones of inhibition were carried out according to the [24] performance standards for antimicrobial susceptibility testing guideline.

\section{Detection of antibiotics resistance genes}

Polymerase chain reaction was performed on isolates that were resistant phenotypically to vancomycin for the presence of putative vancomycin resistance $(\operatorname{van} \mathrm{A}, \operatorname{van} \mathrm{B}$, $v a n \mathrm{C} 1$, and $v a n \mathrm{C} 2 / 3$ ) genes from the previously extracted genomic DNA. PCRs were performed in a BioRad Thermal Cycler (CA, Foster City, USA). The oligonucleotide primers for PCR amplifications were synthesized by Inqaba Biotech (Pretoria, South Africa). Primer sequences for $\operatorname{van} A, \operatorname{van} B, \operatorname{vanC} 1, \operatorname{vanC} 2 / 3$ genes were those previously described by Nam [7] and the list of the specific primers and their amplification products are shown in
Table 2. The reactions were performed as singleplex in a total volume of $25 \mu \mathrm{l}$, using $5 \mu \mathrm{l}$ of cell lysate as DNA template, $10 \mathrm{pMol}$ of each of the eight primers, $12 \mu \mathrm{l}$ of Dream Taq master PCR mix (Inqaba Biotech, Pretoria, South Africa) and $6 \mu \mathrm{l}$ of PCR water grade. Amplification conditions were as follows: a first denaturation step of $94{ }^{\circ} \mathrm{C}$ for $3 \mathrm{~min}, 35$ cycles of denaturation at $94{ }^{\circ} \mathrm{C}$ for $1 \mathrm{~min}$, annealing at $56.5{ }^{\circ} \mathrm{C}$ for $1 \mathrm{~min}$, extension at $72{ }^{\circ} \mathrm{C}$ for $1 \mathrm{~min}$, followed by an elongation step at $72{ }^{\circ} \mathrm{C}$ for $10 \mathrm{~min}$. The PCR products were analyzed on $2 \%$ agarose gel containing $10 \mu \mathrm{l}$ of ethidium bromide, electrophoresed at $110 \mathrm{~V}$ for $45 \mathrm{~min}$ and visualized under UV transilluminator (ALLIANCE 4.7) and photographed.

The presence of erm(B) and strA genes that could have been responsible for the observed resistance to erythromycin and streptomycin were examined by using the primers pairs erm(B) (ermBN1: 5'-CGAGTGAAAAAG TACTCAACCA-3', ermBN2: 5' -CGGTGAATATCCAA GGTACG-3') and strAF: ${ }^{\prime}$-ATCTGTCTGGAGCGGAT TTG-3' and strAR:5'-CCAGTTCTCTTCGGCGTTAG-3' respectively. In each PCR tube, a reaction mixture $(25 \mu \mathrm{l})$ containing $5 \mu \mathrm{l}$ bacterial DNA, $12 \mu \mathrm{l}$ of Dream Taq Master Mix (Thermo Scientific) $10 \mathrm{pMol}$ each of primer and

Table 4 Antibiotic resistance profiles of E. faecium, E. hirae, E. durans and E. faecalis isolates obtained from pig faecal samples

\begin{tabular}{|c|c|c|c|c|c|c|c|c|}
\hline \multirow[t]{2}{*}{ Antibiotics } & \multicolumn{2}{|l|}{ Efaecium } & \multicolumn{2}{|l|}{ E.hirae } & \multicolumn{2}{|l|}{ E.durans } & \multicolumn{2}{|l|}{ E.faecalis } \\
\hline & $\mathrm{R}$ & $S$ & $\mathrm{R}$ & $S$ & $\mathrm{R}$ & S & $\mathrm{R}$ & S \\
\hline VANCOMYCIN & $120(100 \%)$ & $0(0 \%)$ & $100(100 \%)$ & $0(0 \%)$ & $60(100 \%)$ & $0(0 \%)$ & $40(100 \%)$ & $0(0 \%)$ \\
\hline CEPHALOTHIN & 109(90.8 \%) & $11(9.2 \%)$ & 93(93 \%) & $7(7 \%)$ & $50(83 \%)$ & $10(17 \%)$ & $34(85 \%)$ & $6(15 \%)$ \\
\hline PENICILLIN G & $114(95 \%)$ & $6(5 \%)$ & $98(98 \%)$ & $2(2 \%)$ & $45(75 \%)$ & $15(25 \%)$ & $35(87 \%)$ & $5(13 \%)$ \\
\hline CIPROFLOXACIN & $113(94.1 \%)$ & $7(5.9 \%)$ & $87(87 \%)$ & $13(13 \%)$ & $30(50 \%)$ & $30(50 \%)$ & $18(45 \%)$ & $22(55 \%)$ \\
\hline STREPTOMYCIN & $120(100)$ & $0(0 \%)$ & $100(100 \%)$ & $0(0 \%)$ & $60(100 \%)$ & $0(0 \%)$ & $40(100 \%)$ & $0(0 \%)$ \\
\hline AMOXIL/ CLAV & 20(16.7 \%) & $100(83.3 \%)$ & $15(15 \%)$ & $85(85 \%)$ & $15(25 \%)$ & $45(75 \%)$ & 14(35\%) & $26(65 \%)$ \\
\hline AMIKACIN & $117(97.5 \%)$ & $3(2.5 \%)$ & $95(95 \%)$ & $5(5 \%)$ & $40(66.7 \%)$ & $20(33.3 \%)$ & $20(50 \%)$ & $20(50 \%)$ \\
\hline CLINDAMYCIN & $116(96.66 \%)$ & $4(3.44 \%)$ & $100(100 \%)$ & $0(0 \%)$ & $60(100 \%)$ & $0(0 \%)$ & $40(100 \%)$ & $0(0 \%)$ \\
\hline ERYTHROMYCIN & $118(98.3 \%)$ & $2(1.7 \%)$ & $100(100 \%)$ & $0(0 \%)$ & $58(96.7 \%)$ & $2(3.3 \%)$ & $40(100 \%)$ & $0(0 \%)$ \\
\hline NEOMYCIN & $120(100 \%)$ & $0(0 \%)$ & 98(98 \%) & $2(2 \%)$ & $42(70 \%)$ & $18(30 \%)$ & $40(100 \%)$ & $0(0 \%)$ \\
\hline IMIPENEM & $10(8.3 \%)$ & $110(91.7 \%)$ & $9(9 \%)$ & $91(91 \%)$ & $20(33 \%)$ & $40(77 \%)$ & $13(32.5 \%)$ & $27(68.5 \%)$ \\
\hline CLOXACILLIN & $120(100 \%)$ & $0(0 \%)$ & 100(100 \%) & $0(0 \%)$ & $60(100 \%)$ & $0(0 \%)$ & $40(100 \%)$ & $0(0 \%)$ \\
\hline
\end{tabular}




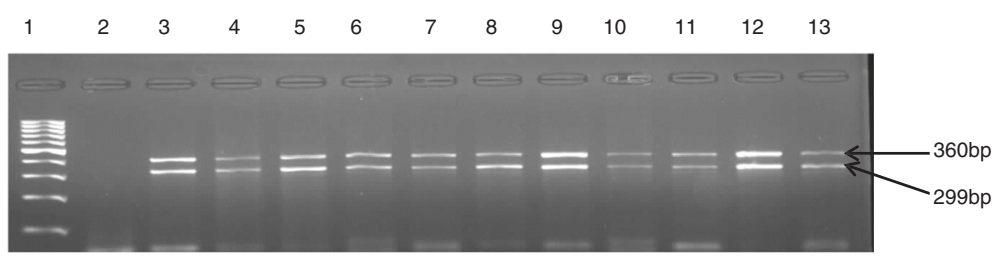

Fig. 4 Phenotypic antibiotic resistance of the Enterococcus isolates recovered from this study

6ul of water of PCR grade was prepared. The reaction mixture in the tube was subjected to 35 PCR cycles of denaturation at $94{ }^{\circ} \mathrm{C}(1 \mathrm{~min})$, annealing at $55{ }^{\circ} \mathrm{C}$ and $56.5{ }^{\circ} \mathrm{C}$ respectively for erm (B) and $\operatorname{str} \mathrm{A}(1 \mathrm{~min})$, and elongation at $72{ }^{\circ} \mathrm{C}(1 \mathrm{~min})$ in a BioRad thermal cycler with a final elongation at $72{ }^{\circ} \mathrm{C}$ for $7 \mathrm{~min}$. PCR products with specific sizes of the resistance genes were detected by agarose gel electrophoresis at $110 \mathrm{~V}$ for $45 \mathrm{~min}$, stained with ethidium bromide and visualized under UV light in a transilluminator (ALLIANCE 4.7).

\section{Screening for virulence genes in Enterococcus spp.}

The presence of virulence genes were investigated from the previously extracted genomic DNA for all the confirmed isolates. Specific primers for the following five virulence genes: ace, efaA, $c y l \mathrm{~A}, g e l \mathrm{E}, e s p$ and $h y l \mathrm{E}$ were used as previously described by [25]. The list of the primers used and their amplification products are reported in Table 3. The reactions were performed in a total volume of $25 \mu \mathrm{l}$ using $5 \mu \mathrm{l}$ of DNA, $10 \mathrm{pmol}$ of each primer, $12 \mu \mathrm{l}$ of PCR Dream Taq Master Mix (Thermo Scientific). PCR conditions for ace and gelE genes were denaturation at $94{ }^{\circ} \mathrm{C}$ for $1 \mathrm{~min}$, annealing at $50{ }^{\circ} \mathrm{C}$ for $1 \mathrm{~min}$, extension at $72{ }^{\circ} \mathrm{C}$ for $1 \mathrm{~min}$ for $35 \mathrm{cy}$ cles and final extension at $72{ }^{\circ} \mathrm{C}$ for $10 \mathrm{~min}$ while those for the amplification of the efaA, esp, cylA and $h y l \mathrm{E}$ genes were as follows: denaturation at $94{ }^{\circ} \mathrm{C}$ for $1 \mathrm{~min}$, annealing at $56.5{ }^{\circ} \mathrm{C}$ for $1 \mathrm{~min}$, extension at $72{ }^{\circ} \mathrm{C}$ for $1 \mathrm{~min}$, for 35 cycles with a final extension at $72{ }^{\circ} \mathrm{C}$ for 10 min. The PCR products were analyzed on $2 \%$ agarose gel containing ethidium bromide, electrophoresed at $110 \mathrm{~V}$ for $45 \mathrm{~min}$, visualized under UV transilluminator (ALLIANCE 4.7) and photographed.

\section{Results}

A total of 320 presumptive isolates were recovered from the 400 fecal samples collected from the breeder pigs in a 600 and 3,000 sizes heard that have been exposed to tylosin, advocin (danofloxacin), ampicillin, and penicillin $\mathrm{G}$ antibiotics. Molecular identification of the presumptive isolates based on the tuf gene specific primers confirmed them to be Enterococcus spp. Representatives of the confirmed isolates are shown in Fig. 1. Attempt at speciation of the isolates with primers specific for $E$. faecalis, E. durans, E. casseliflavus, E. hirae and E. faecium delineated them as follow: E. faecalis (12.5\%), E. hirea (31.25\%), E. durans (18.75\%) and E. faecium (37.5\%) while E. casseliflavus was not detected as shown in Figs. 2 and 3.

\section{Antibiotic susceptibility}

A very high multi-resistance to antibiotics tested was observed among the isolates. All the isolates were resistant to most of the drugs tested against them with vancomycin, streptomycin and cloxacillin have $100 \%$ resistance respectively. Among the 12 antimicrobial agents tested, the frequencies of resistances to penicillin G (91\%), clindamycin (98.72\%), ciprofloxacin (77.5\%), erythromycin (98.72\%), neomycin (93.8\%), amikacin (85\%), cephalothin $(86.3 \%)$ were among the highest while those of imipenem (16.3\%) and amoxicillin/clavulanate (20\%) were least frequent. The phenotypic multi-resistance patterns of the isolates are shown in Table 4 while the percentage resistance is in Fig. 4. All Enterococcus isolates were resistant to at least two different classes of antibiotics, with 300 (93.8 \%) isolates being resistant to five or more antibiotics. Overall, all the isolates recovered demonstrated relatively high resistance levels to agents that are used in the farms which includes penicillin, erythromycin that is selected by tylosin and quinolones (advocin).

\section{Correlation between antibiotic resistance phenotype and genotype}

Specific resistance genes were detected in corresponding phenotypic antibiotic-resistant isolates (Table 5) and some of the detected resistance genes are shown in Figs. 5 and 6. The detected genes include those conferring resistance

Table 5 Predominant multi-resistance pattern observed among the isolates

\begin{tabular}{ll}
\hline No. of isolates & Multiple antimicrobial resistance pattern (phenotypic) \\
\hline 320 & V/CD/S/E/-/CX/PG/NE/INI/CIP \\
7 & V/CD/S/E/AK/CX/PG/NE/KF/CIP/AUG \\
2 & V/IMI/CD/S/E/-/CX/PG/NE/KF \\
12 & V/CX/E/S/PG/CD/CIP/KF/NE \\
250 & V/CD/S/E/AK/CX/PG/NE/KF \\
\hline
\end{tabular}

$\mathrm{V}=$ Vancomycin, $\mathrm{CD}=$ Clindamycin; $\mathrm{S}=$ Streptomycin, $\mathrm{E}=$ Erythromycin; $\mathrm{CIP}=$ Ciprofloxacin; PG = Penicillin G; NE = Neomycin; IMI = Imipenem; KF =

Cephalothin; $A K=$ Amikacin; AUG = Amoxicillin/Clavulanic acid 


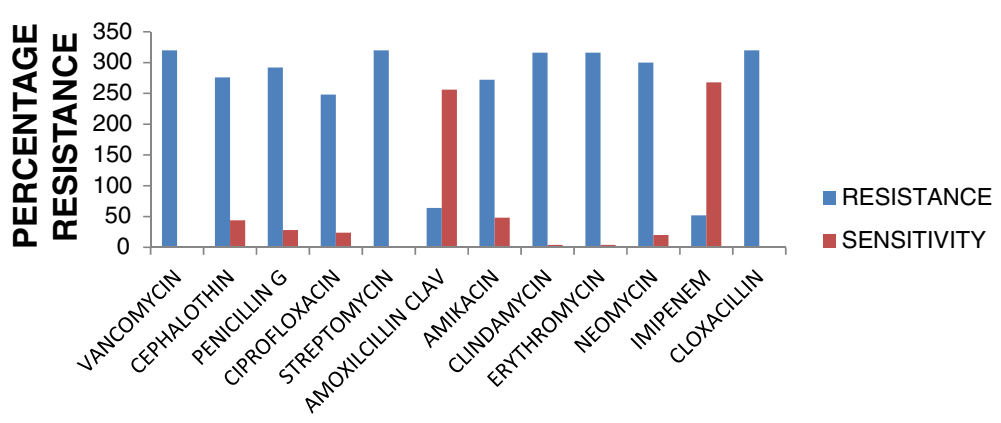

Fig. 5 Gel electrophoresis of PCR products of vancomycin resistant isolates. Lane 1 is 100 bp ladder, lane 2 negative control and lanes 3 to 11 are vanC2/3 (582 bp) positive samples

to streptomycin an aminoglycosides (strA), erythromycin a macrolides (ermB), and vancomycin a glycopeptide $(\operatorname{van} \mathrm{B}, \operatorname{van} \mathrm{C} 1, \operatorname{van} \mathrm{C} 2 / 3)$. The $\operatorname{van} \mathrm{B}, \operatorname{van} \mathrm{C} 1, \operatorname{van} \mathrm{C} 2 / 3$, ermB, and strA genes were present in majority of the identified species of Enterococcus that exhibited phenotypic resistance.

Genetic prevalence of virulence genes among the isolates Among the virulence genes tested, only ace, gelE and esp genes were detected in all almost all the isolates that were genetically profiled. The other virulence genes $(c y l \mathrm{~A}$, $h y l \mathrm{~A}$, and $e f a \mathrm{~A}$ ) were not detected. The prevalence of the virulence genes detected among the isolates is shown in Table 6. The frequencies of the virulence genes are; ace (96.88 \%), gelE (93.13\%) and esp (67.8 \%). Fig. 7 represents the gel picture of the ace and $g y l$ E detected while esp was not shown.

\section{Discussion}

Enterococcus, which exist commensally in the gut of warm-blooded animals and humans, are opportunistic pathogens that cause a variety of community-acquired and health care-associated infections, such as urinary tract and intra-abdominal infections, bacteremia, and endocarditis [26]. Previous reports have shown that epidemiologically distinct Enterococcus spp. possess virulence genes that enable them to establish infections in their host [27] as well as demonstrate high antimicrobial resistance occasioned by their ability to genetically acquire and transmit antimicrobial drug resistant determinants among themselves and other bacteria in their environment [28]. Therefore, we characterized all isolates with respect to these traits. Out of a total of 400 fecal samples collected from breeder pig farms, presumptive isolates recovered from bile aesculine azide medium were 320 and were confirmed as Enterococcus spp.by PCR targeting the tuf gene of the genus Enterococcus. Further characterization of the confirmed 320 isolates by species specific primers delineated them into four species; E. faecium, E. hirae, E. durans and $E$. faecalis in order of their prevalence. Our findings are in partial agreement with those of Hwang[29] who reported a preponderance of E.feacium and E.feacalis in fecal samples of poultry and swine collected at slaughterhouses in South Korea and [30].

The presence of 6 virulence-associated genes (gelE, $h y l \mathrm{~A}, a c e, e s p, e f a \mathrm{~A}$ and $c y l A$ ) was investigated by using gene specific primers that have been described elsewhere [25]. Out of the 6 virulence genes investigated, only three; ace, gelE and esp were detected among the 320 isolates. Our findings are in near agreement with that of Diarra [31] who reported the presence of $g l y \mathrm{E}$ in all isolates they studied in broiler chicken but quite different from that of Mannu [25] who did not detect gelE and ace in meat, cheese and vegetable samples that they analyzed. The main role of both gelatinase and serine protease in enterococcal pathogenesis is thought to be in

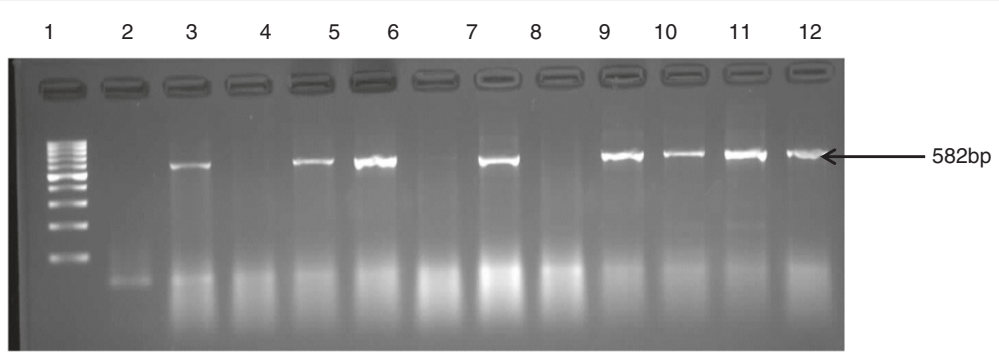

Fig. $6 \mathrm{Gel}$ image of amplicons obtained from erythromycin resistant isolates. Lane 1 is 100 bp ladder, lane 2 negative control and lanes 3 to 11 are ermB (320 bp) positive samples 
Table 6 Prevalence of virulent genes amplified from the study isolates

\begin{tabular}{ll}
\hline Virulent genes & Number of positive \\
\hline ace & $310(96.88 \%)$ \\
ge/E & $298(93.13 \%)$ \\
efaA & 0 \\
hylE & 0 \\
cylA & 0 \\
esp & $217(67.8 \%)$ \\
\hline
\end{tabular}

efaA = E.faecalis antigen $\mathrm{A} ;$ gelE $=$ gelatinase $\mathrm{Ace}=$ Adhesion of collagen in E.faecalis

Eesp = surface protein; cylA = cytolysin; hylE = hyaluronidase

providing nutrients to the bacteria by degrading host tissue and also functions in biofilm formation [32]. Gelatinase (GelE) is an extracellular zinc metalloendopeptidase secreted by E. faecalis $[33,34]$. It is able to hydrolyse gelatin, casein, haemoglobin and other bioactive peptides. The gene (gelE) encoding GelE is located on the chromosome and is regulated in a cell-densitydependent manner. Zou [35] reported also a moderately high presence of efa, gelE and ace virulence genes among $E$. faecalis isolated from swine in China.

The isolates were generally homogenous in terms of presence of virulence-associated genes and it appears from our study that the incidence of known virulence factors in Enterococcus is generally high with majority of the strains carrying more than one virulence determinant.

The genes encoding efaA, hylA and cylA were however not detected. According to Shankar [32], the esp gene encodes an enterococcal surface protein (Esp), which contributes to the colonization and infection of the urinary tract by increasing attachment to epithelial surfaces and biofilm production.

Besides having a huge arsenal of insusceptibilities to physicochemical and environmental stresses [13], Enterococcus generally possess a broad spectrum of natural antibiotic resistances [26]. The propensity for multiple antibiotic resistances is a hallmark of Enterococcus. All Enterococcus are naturally (intrinsically) resistant to many antimicrobial agents such as semisynthetic penicillins (e.g., oxacillin), cephalosporins of all classes, monobactams and polymyxins [37]. Notably, most of the isolates in our study were resistant to the antimicrobials in the panel. Multiple drug resistances were observed among the isolates with the commonest patterns being those of vancomycin, erythromycin and streptomycin. In a study conducted by Diarra [31] on the distribution of antimicrobial resistance of Enterococcus spp. in broiler chicken in Canada, they reported a very high level of antimicrobial resistances among their isolates. However, they did not detect vancomycin resistance among their isolates except in few species of E. gallinarum where vanC gene was present making our finds differ a bit from theirs. Similarly, Peters [38] also reported a similar pattern of occurrence of multidrug resistant strains in a study on assessment of species distribution and antibiotic resistance patterns of enterococcal from food of animal origin in Germany. Brown [39] has reported that if glycopeptide resistant enterococci (GRE) are present in an infected patient rather than an antibiotic-susceptible strain, clinical treatment failure is increased by $20 \%$ and mortality is increased from $27 \%$ to $52 \%$.

The very high level of resistance among the isolates against ciprofloxacin is quite alarming as this is the drug of choice in the treatment of several bacterial infections. It is useful for treating chest, urinary tract, prostatitis, gastroenteritis, bone and joint infections, and some sexually transmitted diseases. Our findings are also in agreement with those of Zou [35] who reported a high level of resistances to erythromycin and ciprofloxacin among Enterococcus spp. isolated from swine in China.

The high prevalence of ciprofloxacin resistance could be attributed to the use of advocin a veterinary approved drug that has danofloxacin as it active ingredient. Danofloxacin is a synthetic fluoroquinolone with broad spectrum antibacterial activity and it is commonly used in the treatment of respiratory disease in chickens, cattle and pigs. Since there is similarity in structure and mode of action between ciprofloxacin and danofloxacin, the possibility of cross resistance arising is very high. Genetic investigation of the isolates for the presence of resistance genes yielded amplicons for the erm $\mathrm{B}, \operatorname{str} \mathrm{A}, \operatorname{van} \mathrm{B}$ and $v a n \mathrm{C} 1 /$ $2 / 3$ respectively. The findings in this study are in agreement with previously reported cases of high prevalence of multiple resistances among enterococcal strains of animal origin [40-50]. Noble [51] reported that the genes

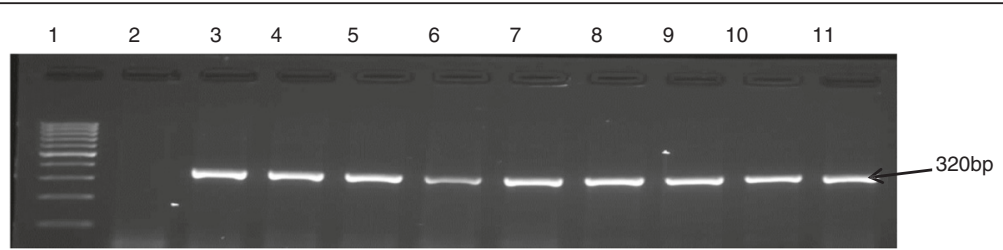

Fig. 7 Agarose gel image of amplicons obtained from a multiplex PCR performed with four Primers specific for the ace and gelE virulent genes of Enterococcus species isolated in this study. Lane 1 is 100 bp ladder, lane 2 negative control and lanes 3 to 13 (ace 320 and gelE 402) are representatives of the positive isolates identified in this study 
responsible for vancomycin resistance have the potential to be transferred to other gram-positive pathogens such as Staphylococcus aureus thus intensifying the public health threat associated with vancomycin and methicillin-resistant S. aureus [52-54, 57-59]. Our findings are also in line with those of Jackson [55] that reported a very high level of aminoglycosides among enterococcal isolated from swine.

The prevalence of antimicrobial resistance among the isolates according to species distribution appears homogeneous as no one species showed disparity with regards to the antimicrobials tested. The high-level resistances among the isolates to neomycin and streptomycin which are the drugs of choice in therapeutic regiments for enterococcal endocarditis should be a major cause of concerns.

Antibiotics may be disseminated into the environment from both human and agricultural sources, including excretion, flushing of old and out-of-date prescriptions, medical waste, discharge from wastewater treatment facilities, leakage from septic systems and agricultural waste-storage structures [56].

Any use of antibiotics will most likely select for drugresistant bacteria especially when applied at subtherapeutic levels as in animal feed. Among the various uses for antibiotics, low-dose, prolonged courses of antibiotics among food animals have the capacity of creating ideal selective pressures for the evolution and selection of resistant strains. Spread of resistance may occur by direct contact or indirectly through food, water, and animal waste application to farm fields. It could also be augmented greatly by the horizontal transfer of genetic elements such as plasmids via bacterial mating (conjugation). For example, Alexander [60], showed that drug-resistant Escherichia coli was present on beef carcasses after evisceration and after $24 \mathrm{~h}$ in the chiller and in ground beef stored for 1 to 8 days. Equally ciprofloxacin-resistant Campylobacter spp. have been isolated from $10 \%$ to $14 \%$ of consumer chicken products [61, 62] while de Boer [63], have reported the presence of MRSA in $12 \%$ of beef, veal, mutton, pork, turkey, fowl, and game samples purchased in the consumer market in the Netherlands as well as in cattle dairy products in Italy [64]. Equally disturbing are the reports of extensive antibiotic resistance among bacteria isolates, including human pathogens, from farmed fish and market shrimp [65-66].

\section{Conclusion}

The prevalence of multiple antibiotic resistance enterococci from fecal samples of pigs is reported here. The data presented showed that the Enterococcus strains that were profiled have the capacity to cause infection as well as having a wide genetic repertoire to survive under antimicrobial pressure. These findings are relevant to public health and contribute to future risk assessment of antimicrobial resistance in zoonotic bacteria. A highlevel rate of resistance to aminoglycosides, macrolides and vancomycin might pose a serious risk in hospitals, as antimicrobial therapy in human medicine could become more limited. These findings suggest that Enterococcus spp. from swine should be treated with utmost caution as they could be reservoirs for antimicrobial resistance and virulence genes.

\section{Abbreviations}

VREs: vancomycin-resistant Enterococcus spp; AGPs: antimicrobial growth promoters; ace: collagen binding cell wall protein; acm: surface-exposed antigen; agg: aggregative pheromone-inducing adherence to extra-matrix protein; esp: enterococcal surface protein; hyl: hyaluronidase; gelE: gelatinase; HIV: human immunodeficiency virus; AIDS: acquired immune deficiency syndrome; PCR: polymerase chain reaction; DNA: deoxyribonucleic acid.

\section{Authors' contribution}

$\mathrm{BCl}$ collected the fecal samples and performed the experiments, $\mathrm{BCl}, \mathrm{LCO}$ and $\mathrm{AIO}$ analyzed data of the study as well as wrote the manuscript. All authors read and approved the final manuscript.

\section{Acknowledgments}

The authors wish to thank the University of Fort Hare and the South Africa Medical Research Council for financial support. The managements of the farms used in this study are appreciated.

Disclosure Statement/Conflict of interest statement

Authors declare that no competing financial interests exist.

\section{Author details}

${ }^{1}$ SA-MRC Microbial Water Quality Monitoring Centre, University of Fort Hare, Alice 5700Eastern Cape, South Africa. ${ }^{2}$ Applied and Environmental Microbiology Research Group, Department of Biochemistry and

Microbiology, University of Fort Hare, Alice 5700Eastern Cape, South Africa. ${ }^{3}$ Academic and Research Division, University of Fort Hare, Alice 5700Eastern Cape, South Africa.

Received: 17 January 2015 Accepted: 18 June 2015

Published online: 04 July 2015

\section{References}

1. Liliana L-M, Diana M, Bessa LJ. A^ ngelo Mendes,Augusto J. de Matos, and Paulo Martins da Costa. Spread of multidrug-resistant Enterococcus faecalis within the household setting. microbial drug resistance. 2014. doi:10.1089/ mdr.2013.0217.

2. Werner G: Current Trends of Emergence and Spread of Vancomycin-Resistant Enterococci. http://www.ecdc.europa.eu/en/publications/Publications/ 1011_SUR_Annual_Epidemiological_Report_on_Communicable_Diseases_ in_Europe.pdf Accessed 20/10/2014. 3)

3. Ghosh A, KuKanich K, Brown CE,and Zurek L: Resident Cats in Small Animal Veterinary Hospitals Carry Multi-Drug Resistant Enterococci and are Likely Involved in Cross-Contamination of the Hospital Environment Front Microbiol. 2012; 3: 62. doi: 10.3389/fmicb.2012.00062

4. Coburn PS, Baghdayan AS, Dolan GT and Shankar N: Horizontal transfer of virulence genes encoded on the Enterococcus faecalis pathogenicity island. Mol Microbiol. 2007; 63: (2), 530-544 DOI: 10.1111/j.1365-2958.2006.05520.

5. Nallapareddy SR, Singh KV, Silanpaa J, Garsin DA, Hook M, Erlandsen SL, et al. Endocarditis and biofilm associated pili of Enterococcus faecalis. J Clin Invest. 2006;116:2799-807.

6. Willems RJ, van Schaik W. Transition of Enterococcus faecium from commensal organism to nosocomial pathogen. Future Microbiol. 2009;4:1125-35.

7. Nam S, Kim MJ, Park C, Park JG, Lee GC. Detection and genotyping of vancomycin-resistant Enterococcus spp. by multiplex polymerase chain reaction in Korean aquatic environmental samples. Int J Hygiene Environ Health. 2012;216(4):421-7. doi:10.1016/j.ijheh.2012.12.004.

8. Ballard SA, Grabsch EA, Johnson PD, Grayson ML. Comparison of three PCR primer sets for identification of vanB gene carriage in feces and correlation with carriage of vancomycin-resistant enterococci: interference by 
vanB-containing anaerobic bacilli. Antimicrob Agents Chemother. 2005:49:77-81.

9. Lester $\mathrm{CH}$, Hammerum AM. Transfer of vanA from an Enterococcus faecium isolate of chicken origin to a CC17 E. faecium isolate in the intestine of cephalosporin-treated mice. J Antimicrob Chemother. 2010;65:1534-6.

10. Top J, Willems R, Bonten M. Emergence of CC17 Enterococcus faecium: from commensal to hospital-adapted pathogen. FEMS Immunol Med Microbiol. 2008;52:297-308.

11. Bearman GML, Wenzel RP. Bacteraemias: a leading cause of death. Arch Med Res. 2005:36:646-59.

12. Woodford N, Adebiyi AM, Palepou MF, Cookson BD. Diversity of VanA glycopeptide resistance elements in enterococci from humans and nonhuman sources. Antimicrob Agents Chemother. 1998;42:502-8.

13. Facklam RR, Carvalho MGS, Teixeira LM. History, taxonomy, biochemical characteristics, and antibiotic susceptibility testing of enterococci. In: Gilmore MS, Clewell DB, Courvalin P, Dunny GM, Murray BE, Rice LB, editors. The enterococci: pathogenesis, molecular biology, and antibiotic resistance. Washington, DC: ASM Press; 2002. p. 1-54.

14. Dutka-Malen S, Molinas C, Arthur M, Courvalin P. Sequence of the vanC gene of Enterococcus gallinarum BM4174 encoding a D-alanine: D-alanine ligase-related protein necessary for vancomycin resistance. Gene. 1994;112:53-8.

15. Leclercq R, Derlot E, Weber M, Duval J, Courvalin P. Transferable vancomycin and teicoplanin resistance in Enterococcus faecium. Antimicrob Agents Chemother. 1989;33:10-5.

16. Werner G, Serr A, Schütt S, Schneider C, Klare I, Witte W, et al. Comparison of direct cultivation on a selective solid medium, polymerase chain reaction from an enrichment broth, and the BD GeneOhm ${ }^{T M}$ VanR Assay for identification of vancomycin-resistant enterococci in screening specimens. Diagnos Microbiol Infect Dis. 2011;70:512-21.

17. Freitas $A R$, Coque $T M$, Novais $C$, Hammerum AM, Lester CH, Zervos MJ, et al. Human and swine hosts share vancomycin-resistant Enterococcus faecium CC17 and CC5 and Enterococcus faecalis CC2 clonal clusters harboring Tn1546 on indistinguishable plasmids. J Clin Microbiol. 2011;49:925-31.

18. Boerlin P, Wissing A, Aarestrup FM, Frey J, Nicolet J. Antimicrobial growth promoter ban and resistance to macrolides and vancomycin in enterococci from pigs. J Clin Microbiol. 2001;39:4193-5.

19. Hancock LE, Gilmore MS. Pathogenicity of enterococci. In: Fischetti VA, Novick RP, Ferretti JJ, Portnoy DA, Rood Jl, editors. Gram-positive pathogens. 2nd ed. Washington, DC: ASM Press; 2006.

20. Klibi NK, Slama B, Saenz Y, Masmoudi A, Zanetti S, Sechi LA, et al. Detection of virulence factors in high-level gentamicin-resistant Enterococcus faecalis and Enterococcus faecium isolates from a Tunisian hospital. Can. J. Microbiol. 2007:53:372-9.

21. Valenzuela AS, Omar NB, Abriouel H, Lo'pez RL, Veljovic K, Cañamero MM, et al. Virulence factors, antibiotic resistance, and bacteriocins in enterococci from artisan foods of animal origin. Food Cont. 2009;20:381-5.

22. Danbing K, Picard FJ, Martineau F, Ménard C, Roy PH, Ouellette M, et al. Development of a PCR Assay for Rapid Detection of Enterococci. J Clin Microbiol. 1999:37(11):3497-503.

23. Jackson CR, Fedorka-Cray PJ, Barrett JB. Use of a Genus-and Species-Specific Multiplex PCR for Identification of Enterococci. JClin Microbiol. 2004;42(8):3558. doi:10.1128/JCM.42.8.3558-3565.

24. Clinical and Laboratory Standards Institute: Performance Standards for Antimicrobial Susceptibility Testing; Twenty-Fourth Informational Supplement 2014.

25. Mannu L, Paba A, Daga E, Comunian R, Zanetti S, Dupre I, et al. Comparison of the incidence of virulence determinants and antibiotic resistance between Enterococcus faecium strains of dairy, animal and clinical origin. Int J Food Microbiol. 2003;88:291-304.

26. Arias CA, Murray BE. Enterococcus species, Streptococcus bovis group and Leuconostoc species. In: Mandell GL, Bennett JE, Dolin R, editors. Mandell, Douglas and Bennett's principles and practice of infectious diseases. 7th ed. Philadelphia: Elsevier; 2010. p. 2643-53.

27. Larsen J, Schønheyder HC, Lester CH, Olsen SS, Porsbo LJ, Garcia-Migura L. Porcine-origin gentamicin-resistant Enterococcus faecalis in humans, Denmark. Emerg Infect Dis. 2010;16:682-71.

28. Fisher $K$ and Phillips $C$. The ecology, epidemiology and virulence of Enterococcus. Microbiol. 2009; 155: 1749-1757 DOI 10.1099/mic.0.026385-0.

29. Hwang IY, Ho K, Lim SK, Park CK, Jung GS, Jung SC, et al. (2009). Species distribution and resistance patterns to growth-promoting antimicrobials of enterococci isolated from pigs and chickens in Korea. J Vet Diag Invest. 2009;21(6):858-62. doi:10.1177/104063870902100616.
30. Dang Son Thi Thanh Andreas P, Dung Van T, Huong Thi Thanh C, Anders D. Impact of medicated feed on the development of antimicrobial resistance in bacteria at integrated Pig-fish farms in Vietnam. Appl Environ Microbiol. 2011;77(13):4494-8.

31. Diarra MS, Champagne J, Rempel H, Topp E, Greer CW, Harel J, et al. Distribution of antimicrobial resistance and virulence genes in Enterococcus spp. and characterization of isolates from broiler chickens. Appl Environ Microbiol. 2010;76:8033-43.

32. Shankar N, Lockatell CV, Baghdayan AS, Drachenberg C, Gilmore MS, Johnson DE. Role of Enterococcus faecalis surface protein Esp in the pathogenesis of ascending urinary tract infection. Infect Immun. 2011;69:4366-72.

33. Nallapareddy SR, Singh KV, Okhuysen PC, Murray BE. A functional collagen adhesin gene, acm, in clinical isolates of Enterococcus faecium correlates with the recent success of this emerging nosocomial pathogen. Infect Immun. 2008;76:4110-9.

34. Sifri CD, Mylonakis E, Singh KV, Qin X, Garsin DA, Myurray BE, et al. Virulence effect of Enterococcus faecalis protease genes and the quorum-sensing locus fsr in Caenorhabditis elegans and mice. Infect Immun. 2002;70:5647-50.

35. Zou LK, Wang HN, Zeng B, Li JN, Li XT, Zhang AY, et al. Erythromycin resistance and virulence genes in Enterococcus faecalis from swine in China. New Microbiol. 2011;234(1):73-80.

36. Garcia-Migura L, Pleydell E, Barnes S, Davies RH, Liebana E. Characterization of Vancomycin-Resistant Enterococcus faecium Isolates from Broiler Poultry and Pig Farms in England and Wales. J Clin Microbiol. 2005;43(Suppl7):3283-9.

37. Peters J, Mac K, Wichmann-Schauer H, Klein G, Ellerbroek L. Species distribution and antibiotic resistance patterns of enterococci isolated from food of animal origin in Germany. Int J Food Microbiol. 2003;88:311-4.

38. Brown DFJ, Brown NM, Cookson BD, Duckworth G, Farrington M, French GL, et al. National glycopeptide-resistant enterococcal bacteraemia surveillance Working Group report to the Department of Health. J Hosp Infect. 2006;62 Suppl 1:1-27.

39. Huycke MM, Sahm DF, Gilmore MS. Multiple-drug resistant enterococci: the nature of the problem and an agenda for the future. Emerg Infect Dis. 1998;: 239-49.

40. Bager F, Madsen M, Christensen J, Aarestrup FM. Avoparcin used as a growth promoter is associated with the occurrence of vancomycin resistant Enterococcus faecium on Danish poultry and pig farms. Prev Vet Med. 1997;31:95-112.

41. Bates J, Jordens JZ, Griffiths DT. Farm animals as a putative reservoir for vancomycin-resistant enterococcal infection in man. J Antimicrob Chemother. 1994;34:507-14.

42. Bates J. Epidemiology of vancomycin-resistant enterococci in the community and the relevance of farm animals to human infection. J Hosp Infect. 1997;37:89-101.

43. Berchieri A. Intestinal colonization of a human subject by vancomycin resistant Enterococcus faecium. Clin Microbiol Infect. 1999;5:97-100.

44. Bonten MJ, Willems R, Weinstein RA. Vancomycin-resistant enterococci: why are they here, and where do they come from? Lancet Infect Dis. 2001;1:314-25.

45. Borgen K, Wasteson Y, Kruse H, Willems RJ. Vancomycin resistant Enterococcus faecium (VREF) from Norwegian poultry cluster with VREF from poultry from the United Kingdom and The Netherlands in an amplified fragment length polymorphism genogroup. Appl Environ Microbiol. 2002;68:3133-7.

46. Boyd DA, Willey BM Fawcett D, Gillani N, Mulvey MR. "Molecular characterization of Enterococcus faecalis N06-0364 with low-level vancomycin resistance harboring a novel D-Ala-D-Ser gene cluster, vanL,". Antimicrob Agents Chemother. 2008;52 Suppl 7:2667-72.

47. Cetinkaya Y, Falk P, Mayhall CG. "Vancomycin resistant enterococci,". Clin Microbiol Rev. 2000;13(4):686-707.

48. Spigaglia P, Barbanti F, Mastrantonio P. on behalf of the European Study Group on Clostridium difficile (ESGCD): Multidrug resistance in European Clostridium difficile clinical isolates. J Antimicrob Chemother. 2011;66:2227-34.

49. Xu X, Lin D, Yan G, Ye X, Wu S, Guo Y, et al. vanM, a new glycopeptide resistance gene cluster found in Enterococcus faecium. Antimicrob Agents Chemother. 2010;54:4643-7.

50. Noble WC, Virani Z, Cree RG. Co-transfer of vancomycin and other resistance genes from Enterococcus faecalis NCTC 12201 to Staphylococcus aureus. FEMS Microbiol Lett. 1992;72:195-8.

51. Iversen A, Kuhn I, Franklin A, Mollby R. High prevalence of vancomycin-resistant enterococci in Swedish sewage. Appl Environ Microbiol. 2002;68:2838-42. 
52. Aarestrup FM, Hasman $H$, Jensen LB, Moreno M, Herrero IA, Dominguez L, et al. Antimicrobial resistance among enterococci from pigs in three European countries. Appl Environ Microbiol. 2002;68:4127-9.

53. Aarestrup FM, Kruse H, Tast E, Hammerum AM, Jensen LB. Associations between the use of antimicrobial agents for growth promotion and the occurrence of resistance among Enterococcus faecium from broilers and pigs in Denmark, Finland, and Norway. Microb Drug Resist. 2000;6:63-70.

54. Jackson CR, Fedorka-Cray PJ, Barrett JB, Ladely SR. 2005. High-level aminoglycoside resistant enterococci isolated from swine. Epidemiol Infect. 2005;133:367-71.

55. Sarmah AK, Michael T, Meyer MT, Boxall ABA. A global perspective on the use, sales, exposure pathways, occurrence, fate and effects of veterinary antibiotics (VAs) in the environment. Chemosph. 2006;65:725-59.

56. Tenover FC, Weigel LM, Appelbaum PC, McDougal LK, Chaitram J, McAllister $S$, et al. Vancomycin-resistant Staphylococcus aureus isolate from a patient in Pennsylvania. Antimicrob Agents Chemother. 2004;48:275-80.

57. Weigel LM, Clewell DB, Gill SR, Clark NC, McDougal LK, Flannagan SE, et al. Genetic analysis of a high-level vancomycin-resistant isolate of Staphylococcus aureus. Sci. 2003;302:1569-71.

58. Lebreton F, Depardieu F, Bourdon N. D-Ala-D-Ser VanN-type transferable vancomycin resistance in Enterococcus faecium. Antimicrobial Agents and Chemother. 2011;55 Suppl 10:4606-12.

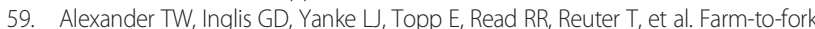
characterization of Escherichia coli associated with feedlot cattle with a known history of antimicrobial use. Int J Food Microbiol. 2010;137:40-8.

60. Gupta A, Nelson JM, Barrett TJ, Tauxe RV, Rossiter SP, Friedman CR, et al. Antimicrobial resistance among Campylobacter strains, United States, 1997-2001. Emerg Infect Dis. 2004;10:1102-9.

61. Smith KE, Besser JM, Hedberg CW. Quinolone-resistant Campylobacter jejuni infections in Minnesota, 1992-1998. N Engl J Med. 1999;340:1525-32.

62. de Boer E, Zwartkruis-Nahuis JT, Wit B, Huijsdens XW, de Neeling AJ, Bosch T, et al. Prevalence of methicillin-resistant Staphylococcus aureus in meat. Int J Food Microbiol. 2009;134:52-6.

63 Normanno G, Corrente M, Salandra GL, Dambrosio A, Quaglia NC, Parisi A, et al. Methicillin-resistant Staphylococcus aureus (MRSA) in foods of animal origin product in Italy. Int J Food Microbiol. 2007;117:219-22.

64. Duran GM, Marshall DL. Ready-to-eat shrimp as an international vehicle of antibiotic-resistant bacteria. J Food Prot. 2005;68:2395-401.

65. Heuer OE, Kruse H, Grave K, Collignon P, Karunasagar I, Angulo FJ. Human health consequences of use of antimicrobial agents in aquaculture. Clin Infect Dis. 2009;49:1248-53.

66. Sorum H. Antibiotic resistance in aquaculture. Acta Vet Scand. 1999:92:29-36.

\section{Submit your next manuscript to BioMed Central and take full advantage of:}

- Convenient online submission

- Thorough peer review

- No space constraints or color figure charges

- Immediate publication on acceptance

- Inclusion in PubMed, CAS, Scopus and Google Scholar

- Research which is freely available for redistribution

Submit your manuscript at www.biomedcentral.com/submit 